\title{
PENGARUH BAURAN PEMASARAN TERHADAP KEPUTUSAN
} PEMBELIAN DI INDOGROSIR CIBINONG

\author{
${ }^{1)}$ Benny Osta Nababan, ${ }^{2)}$ Ramadhan \\ ${ }^{1)}$ Dosen Program Studi Manajemen, STIE Dewantara \\ J1. Raya Pemda Bojong Depok Baru III, Karadenan, Cibinong, Bogor, Jawa Barat 16913,Indonesia \\ Email: benny.osta@dewantara.ac.id \\ ${ }^{2)}$ Alumni Program Studi Manajemen, STIE Dewantara \\ J1. Raya Pemda Bojong Depok Baru III, Karadenan, Cibinong, Bogor, Jawa Barat 16913,Indonesia \\ Email: rmdhnadan21@gmail.com
}

\begin{abstract}
This study aims to determine the effect of the marketing mix including products, prices, promotions, and locations, both simultaneously and partially on purchasing decisions at Indogrosir Cibinong. The results of data analysis show that the product, price and location have a significant effect on purchasing decisions while the promotion has no significant effect on purchasing decisions. The marketing mix consisting of products, prices, promotions and purchasing decisions jointly influences purchasing decisions. The coefficient of determination $\left(R^{2}\right)$ is 0.351 which means that $35.1 \%$ of purchasing decisions in Indogrosir Cibinong are influenced by product variables, price, promotion, and location, while the remaining $64.9 \%$ is influenced by other variables outside the research. Suggestions that can be given in this study are: (1) Indogrosir Cibinong should pay attention to product factors by paying attention to products that are not close to expiration, good quality products, attractive packaging, and not dusty and neat; (2) Price factor by providing affordable prices, prices according to product quality, prices listed in accordance with the price that must be paid, the price offered is competitive and relatively cheap, and prices are in accordance with the benefits of the product; (3) Location factors by paying attention to parking arrangements, parking areas of two or fourwheeled vehicles are quite adequate, the location of Indogrosir is easily accessible by public transportation, as well as the strategic location of Indogrosir.
\end{abstract}

Keywords: Marketing Mix, Purchase Decision, Indogrosir.

\begin{abstract}
ABSTRAK
Penelitian ini bertujuan untuk mengetahui pengaruh bauran pemasaran meliputi terhadap keputusan pembelian di Indogrosir Cibinong. Hasil analisis data menunjukkan bahwa produk, harga dan lokasi berpengaruh signifikan terhadap keputusan pembelian sedangkan promosi tidak berpengaruh signifikan terhadap keputusan pembelian. Bauran pemasaran yang terdiri dari produk, harga, promosi dan keputusan pembelian secara bersama-sama berpengaruh terhadap keputusan pembelian. Koefisien determinasi $\left(\mathrm{R}^{2}\right)$ sebesar 0,351 dapat diartikan bahwa 35,1\% keputusan pembelian di Indogrosir Cibinong dipengaruhi oleh variabel produk, harga, promosi, dan lokasi, sedangkan sisanya sebesar 64,9\% dipengaruhi oleh variabel lain diluar penelitian. Saran yang dapat diberikan dalam penelitian ini yaitu : (1) Indogrosir Cibinong hendaknya memperhatikan faktor produk dengan cara memperhatikan produk yang tidak mendekati kadaluarsa, produk berkualitas baik, kemasan menarik, dan tidak berdebu serta rapi; (2) Faktor harga dengan cara memberikan harga yang terjangkau, harga sesuai dengan kualitas produk, harga yang tertera sesuai dengan harga yang harus di bayar, harga yang ditawarkan kompetitif dan relatif murah, serta harga sesuai dengan manfaat produk; (3) Faktor lokasi dengan cara memperhatikan penataan parkir, area parkir kendaraan roda dua atau empat cukup memadai, lokasi Indogrosir mudah dijangkau oleh transportasi umum, serta penempatan lokasi Indogrosir yang strategis.
\end{abstract}

Kata kunci: Bauran Pemasaran, Keputusan Pembelian, Indogrosir. 


\section{PENDAHULUAN}

\subsection{Latar Belakang}

Keberadaan bisnis ritel modern menjadi semakin penting karena adanya pergeseran pola belanja masyarakat yang lebih suka berbelanja di pasar ritel modern seperti minimarket, supermarket dan hypermarket. Masyarakat menjadi lebih gemar untuk berbelanja di pasar ritel modern dimana masyarakat bisa mendapatkan kepraktisan dan kecepatan dalam berbelanja. Pergeseran pola belanja tersebut disebabkan karena konsumen saat ini semakin menginginkan kenyamanan dalam berbelanja, kepastian harga, pelayanan yang memuaskan, tersedianya kelangkaan produk yang berkualitas, lokasi yang strategis serta promosi yang menarik minat beli. Hal tersebut inilah yang kemudian membuat industri ritel modern berkembang sangat cepat.

Salah satu cara untuk memenangkan paxsar adalah melalui perencanaan taktis. Menurut Shinta (2011:24) perencanaan taktis ini menggunakan konsep bauran pemasaran (Marketing Mix) yang merupakan perangkat alat pemasaran taktis yang dapat dikendalikan dan dipadukan oleh perusahaan untuk menghasilkan respon yang diinginkan pasar sasaran. Bauran pemasaran harus bersifat dinamis dan dapat menyesuaikan diri dengan lingkungan eksternal maupun internal. Menurut Utami (2010:86) dalam Meita Dwirachmawati (2014:2) faktor internal terdiri dari 4P yaitu produk (product), harga (price), promosi (promotion), dan tempat (place).

Keempat variabel bauran pemasaran memiliki fungsi masing-masing yang saling berkaitan. Hal tersebut seperti yang dikemukakan oleh Kotler dan Keller (2008:4) bahwa produk merupakan segala sesuatu yang dapat ditawarkan kepada pasar untuki memuaskan suatu keinginan atau kebutuhan, termasuki barangi fisik, jasa, pengalaman, acara, orang, tempat, properti, organisasi, informasi, dan ide. Selain unsur produk, harga merupakan satu-satunya unsur bauran pemasaran yang memberikan pemasukan atau pendapatan bagi perusahaan, sedangkan ketiga unsur lainnya (produk, tempat, dan promosi) menyebabkan timbulnya biaya/pengeluaran (Tjiptono, 2008:151).

Kinerja Indogrosir Cibinong yang sangat baik terlihat dari perkembangan penjualan yang terus meningkat signifikan dari setiap tahunnya. Adapun data jumlah penjualan Indogrosir Cibinong selama tiga tahun terakhir yang dapat dilihat pada Gambar 1.

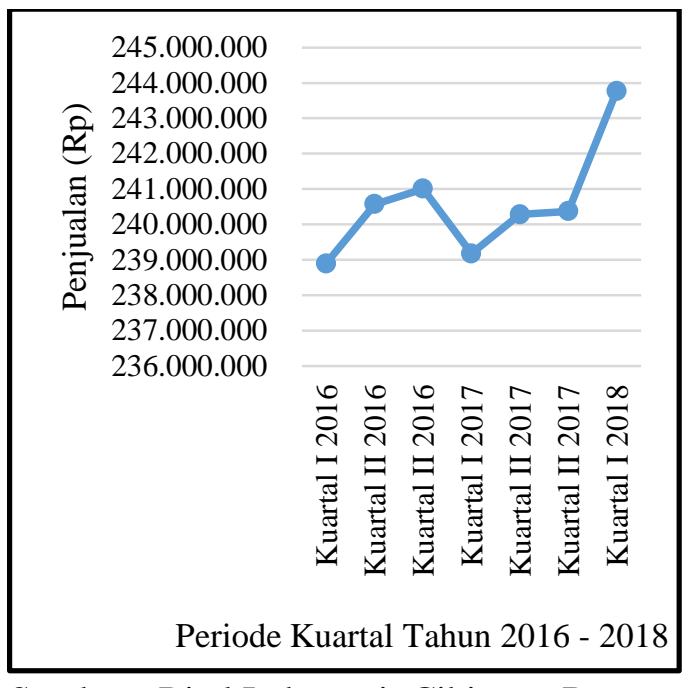

Sumber : Ritel Indogrosir Cibinong Bogor (2016-2017)

\section{Gambar 1. Data Penjualan Ritel Indogrosir Cibinong, Bogor 2016-2018}

Gambar 1 menunjukkan data penjualan ritel Indogrosir Cibinong dari tahun 2016 sampai 2018, dengan pembagian 3 kuartal periode penjualan. Dalam kuartal pertama, kedua dan ketiga di tahun 2016 penjualan mengalami fluktuasi yang tidak terlalu besar. Namun pada kuartal selanjutnya di tahun 2017 penjualan Indogrosir Cibinong cenderung mengalami penurunan penjualan dibandingkan dengan penjualan di tahun 2016. Tahun 2018 penjualan mengalami peningkatan fluktuasi yang tidak terlalu 


besar dari tahun 2017. Terjadinya
penurunan daya jual dari Indogrosir Cibinong ini diduga diakibatkan oleh unsurunsur pemasaran yang tidak berfungsi dengan baik.

Berdasarkan data di atas terlihat bahwa terjadi penurunan pada tahun 2017. Ketatnya persaingan ritel menuntut Indogrosir untuk terus bersaing dan menentukan strategi agar penjualan perusahaan semakin meningkat, karena itu Indogrosir harus mempunyai penerapan strategi yang tepat. Hadirnya Indogrosir dengan konsep bauran ritel yang lengkap dan terbaik diharapkan mampu menarik minat para konsumen untuk berkunjung dan berbelanja di gerainya. Strategi pemasaran yang dijalankan Indogrosir Cibinong antara lain menyediakan produk berkualitas dan lengkap, menawarkan harga bersaing dengan promo dan diskon pada produk tertentu, desain toko dan presentasi barang yang menarik, layanan pelanggan yang baik dan berlokasi strategis.

\subsection{Tujuan Penelitian}

Tujuan penelitian ini adalah :

1. Mengetahui pengaruh variabel dari bauran pemasaran yang terdiri dari produk, harga, promosi, dan lokasi secara parsial terhadap keputusan pembelian di Indogrosir Cibinong.

2. Mengetahui pengaruh variabel dari bauran pemasaran yang terdiri dari produk, harga, promosi, dan lokasi secara simultan terhadap keputusan pembelian di Indogrosir Cibinong.

3. Mengetahui variabel bauran pemasaran yang paling mempunyai pengaruh dominan terhadap keputusan pembelian di Indogrosir Cibinong.

4. Mengetahui bagaimana variabel bauran pemasaran dapat menjelaskan variabel keputusan pembelian di Indogrosir Cibinong.

\section{TINJAUAN PUSTAKA}

Menurut Shinta (2011:24), salah satu cara untuk memenangkan pasar adalah melalui perencanaan taktis dimana perencanaan taktis ini menggunakan konsep bauran pemasaran (Marketing Mix) yang merupakan perangkat alat pemasaran taktis yang dapat dikendalikan dan dipadukan oleh perusahaan untuk menghasilkan respon yang diinginkan pasar sasaran. Dalam bauran pemasaran untuk meningkatkan jumlah kualitas dan kuantitas suatu pelayanan, maka diperlukan penerapan strategi pemasaran. penerapan bauran pemasaran berupa produk (product), harga (price), promosi (promotion), dan lokasi (place) yang akan berpengaruh terhadap keputusan pembelian konsumen. Secara rinci definisi operasional yang digunakan dalam penelitian ini disajikan dalam Tabel 1.

Tabel 1. Definisi Operasional

\begin{tabular}{|c|c|c|c|}
\hline $\begin{array}{l}\mathbf{N} \\
\mathbf{0}\end{array}$ & Variabel & $\begin{array}{c}\text { Definisi } \\
\text { Operasiona } \\
\text { l }\end{array}$ & Indikator \\
\hline 1. & $\begin{array}{l}\text { Produk }\left(\mathrm{X}_{1}\right) \\
\text { Kotler dan } \\
\text { Armstrong } \\
(2012: 52)\end{array}$ & $\begin{array}{l}\text { Mengelola } \\
\text { unsur } \\
\text { produk } \\
\text { termasuk } \\
\text { perencanaan } \\
\text { dan } \\
\text { pengembang } \\
\text { an produk } \\
\text { dan jasa } \\
\text { yang tepat } \\
\text { untuk } \\
\text { dipasarkan } \\
\text { dengan } \\
\text { mengubah } \\
\text { produk atau } \\
\text { jasa yang } \\
\text { ada dengan } \\
\text { menambah } \\
\text { dan } \\
\text { mengambil } \\
\text { tindakan } \\
\text { yang lain } \\
\text { yang }\end{array}$ & $\begin{array}{l}\text { Kualitas } \\
\text { Produk } \\
\text { Kemasan } \\
\text { Produk }\end{array}$ \\
\hline
\end{tabular}


Economicus, Vol. 12 No. 2 -Desember 2018

e- ISSN: $2615-8078$

\begin{tabular}{|c|c|c|c|c|c|c|c|}
\hline \multirow[t]{3}{*}{$\begin{array}{l}\mathbf{N} \\
\mathbf{0}\end{array}$} & Variabel & $\begin{array}{c}\text { Definisi } \\
\text { Operasiona } \\
1 \\
\end{array}$ & Indikator & $\begin{array}{l}\mathbf{N} \\
\mathbf{0}\end{array}$ & Variabel & $\begin{array}{c}\text { Definisi } \\
\text { Operasiona } \\
1\end{array}$ & Indikator \\
\hline & & $\begin{array}{l}\text { mempengar } \\
\text { uhi } \\
\text { bermacam- } \\
\text { macam } \\
\text { produk atau }\end{array}$ & & & & $\begin{array}{l}\text { untuk } \\
\text { mencapai } \\
\text { target } \\
\text { konsumen. }\end{array}$ & \\
\hline & & jasa. & & 5. & $\begin{array}{l}\text { Keputusan } \\
\text { Pembelian }\end{array}$ & $\begin{array}{l}\text { Suatu proses } \\
\text { dimana }\end{array}$ & $\begin{array}{l}\text { Pengenalan } \\
\text { masalah }\end{array}$ \\
\hline 2. & $\begin{array}{l}\text { Harga }\left(\mathrm{X}_{2}\right) \\
\text { Kotler dan } \\
\text { Keller } \\
(2010: 278)\end{array}$ & $\begin{array}{l}\text { Sejumlah } \\
\text { uang yang } \\
\text { dibebankan } \\
\text { atas suatu } \\
\text { produk atau } \\
\text { jasa, atau } \\
\text { jumlah dari } \\
\text { nilai yang } \\
\text { ditukar } \\
\text { konsumen } \\
\text { atas } \\
\text { manfaat- } \\
\text { manfaat } \\
\text { karena } \\
\text { memiliki } \\
\text { atau } \\
\text { menggunaka } \\
\text { n produk }\end{array}$ & $\begin{array}{l}\text { Keterjangka } \\
\text { uan harga } \\
\text { Kesesuaian } \\
\text { harga } \\
\text { dengan } \\
\text { kualitas } \\
\text { produk } \\
\text { Daya saing } \\
\text { harga } \\
\text { Kesesuaian } \\
\text { harga } \\
\text { dengan } \\
\text { manfaat }\end{array}$ & & $\begin{array}{l}(\mathrm{Y}) \\
\text { Kotler dan } \\
\text { Keller } \\
(2008: 184)\end{array}$ & $\begin{array}{l}\text { konsumen } \\
\text { melakukan } \\
\text { penilaian } \\
\text { terhadap } \\
\text { berbagai } \\
\text { alternatif } \\
\text { pilihan dan } \\
\text { memilih } \\
\text { salah satu } \\
\text { atau lebih } \\
\text { alternatif } \\
\text { yang } \\
\text { diperlukan } \\
\text { berdasarkan } \\
\text { pertimbanga } \\
\text { n tertentu } \\
\text { dalam } \\
\text { pembelian. }\end{array}$ & $\begin{array}{l}\text { Pencarian } \\
\text { informasi } \\
\text { Evaluasi } \\
\text { alternatif } \\
\text { Keputusan } \\
\text { pembelian } \\
\text { Perilaku } \\
\text { pasca } \\
\text { pembelian }\end{array}$ \\
\hline
\end{tabular}

Berdasarkan definisi operasional pada Tabel 1, maka dapat diuraikan bauran pemasaran ritel terhadap keputusan pembelian di Indogrosir Cibinong secara jelas melalui kerangka penelitian pada Gambar 2.

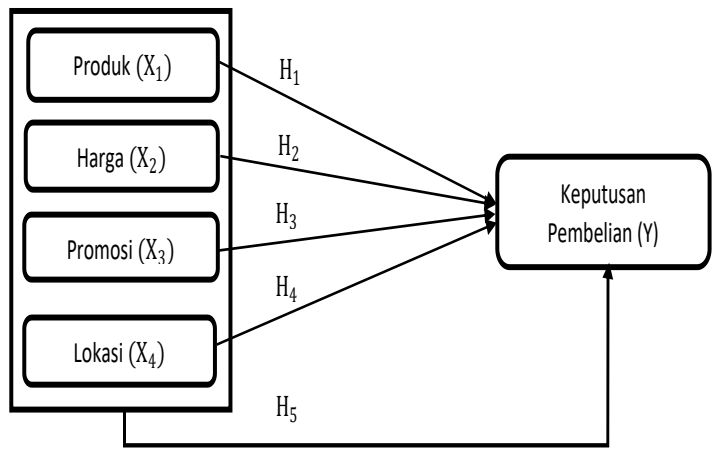

Gambar 2. Kerangka penelitian 
3. METODE PENELITIAN

\subsection{Lokasi dan Waktu Penelitian}

Penelitian ini dilakukan di Indogrosir Cibinong yang berlokasi di Jalan Raya Bogor - Jakarta No.46,7, Nanggewer Mekar, Cibinong, Bogor, Jawa Barat 16912. Penelitian ini dilaksanakan pada bulan Juni 2018 di Indogrosir Cibinong.

\subsection{Populasi dan Sampel}

Obyek penelitian adalah konsumen Indogrosir Cibinong. Populasi penelitian ini adalah seluruh konsumen yang melakukan pembelian di Indogrosir Cibinong berdasarkan data kunjungan bulan sebelumnya yaitu tanggal 1 sampai $31 \mathrm{Mei}$ 2018. Rata-rata jumlah konsumen Indogrosir Cibinong per hari yaitu sebesar 521 orang (Ritel Indogrosir Cibinong Bogor, 2018)

Sampel adalah bagian dari jumlah dan karakteristik yang dimiliki oleh populasi sehingga sampel dalam penelitian ini merupakan sebagian konsumen Indogrosir Cibinong yang pernah berbelanja di Indogrosir Cibinong. Pengukuran sampel dari populasi dengan menggunakan metode Slovin sebagai berikut :

$$
\begin{aligned}
\mathrm{n} & =\frac{521}{1+521(0,1)^{2}} \\
& =84 \text { orang }
\end{aligned}
$$

Sampel minimum yang digunakan dalam penelitian ini sebesar 84 responden, namun untuk menghindari kesalahan maka penelitian ini menggunakan sampel sebanyak 100 responden.

\subsection{Teknik Pengumpulan Data}

Pengumpulan data dalam penelitian ini menggunakan metode survei dengan teknik incidental sampling yaitu teknik pengumpulan data berdasarkan kebetulan, yaitu siapa saja yang secara kebetulan/ incidental bertemu dengan peneliti dapat digunakan sebagai sampel, bila dipandang orang yang kebetulan ditemui itu cocok sebagai sumber data (Sugiyono,2011).
Alat yang digunakan dalam pengumpulan data ini yaitu kuesioner untuk memperoleh data pengaruh bauran pemasaran yang meliputi produk, harga, promosi, lokasi, terhadap keputusan pembelian konsumen di Indogrosir Cibinong. Kuesioner terdiri dari pertanyaan dengan jawaban telah disediakan dengan menggunakan skala Likert meliputi lima jenjang tingkatan seperti yang disampaikan pada Tabel 2 .

Tabel 2. Skala Likert

\begin{tabular}{|c|c|}
\hline $\begin{array}{c}\text { Alternatif Jawaban } \\
\text { Sangat Tidak Setuju } \\
\text { (STS) }\end{array}$ & Skor Penilaian (+) \\
\hline Tidak Setuju (TS) & 2 \\
\hline Kurang Setuju (KS) & 3 \\
\hline Setuju (S) & 4 \\
\hline Sangat Setuju (SS) & 5 \\
\hline
\end{tabular}

\subsection{Analisis Data}

Teknik analisis data yang digunakan dalam penelitian antara lain :

\subsubsection{Uji Validitas}

Uji validitas menunjukan sejauh mana alat pengukur yang dipergunakan untuk mengukur apa yang diukur. Caranya adalah dengan mengkolerasikan antara skor yang diperoleh pada masing-masing item pertanyaan dengan skor total individu.

\subsubsection{Uji Reliabilitas}

Uji reliabilitas untuk mengetahui tingkat konsistensi terhadap instrumeninstrumen dalam mengukur konsep. Tinggi rendahnya realibilitas, secara empirik ditunjukan oleh suatu angka yang disebut koefisien realibilitas yaitu Teknik Cronbach Alpha.

\subsubsection{Uji Asumsi Klasik}

Uji prasyarat analisis digunakan sebelum melakukan analisis terhadap data yang telah diperoleh. Untuk mengetahui prasyarat tersebut maka dalam penelitian ini 


diperlukan uji normalitas, uji
multikolinearitas dan uji heterokedasitisitas.

\subsubsection{Analisis Regresi Berganda}

Dalam analisis ini dapat dilihat seberapa besar variabel bebas, yaitu variabel produk $\left(\mathrm{X}_{1}\right)$, harga $\left(\mathrm{X}_{2}\right)$, promosi $\left(\mathrm{X}_{3}\right)$, dan lokasi $\left(\mathrm{X}_{4}\right)$ berpengaruh terhadap variabel terikat, yaitu keputusan pembelian konsumen (Y). Adapun bentuk persamaan regresi linier berganda yang digunakan dalam penelitian ini sebagai berikut:

$$
Y=\alpha+\beta_{1} X_{1}+\beta_{2} X_{2}+\beta_{3} X_{3}+\beta_{4} X_{4}+e
$$

Keterangan:

$$
\begin{aligned}
\mathrm{Y}= & \text { keputusan pembelian konsumen di } \\
& \text { Indogrosir Cibinong } \\
\alpha= & \text { konstanta dari keputusan regresi } \\
\beta_{1}= & \text { koefisien regresi dari variabel } \mathrm{X}_{1} \\
& \text { (produk / product) } \\
\beta_{2}= & \text { koefisien regresi dari variabel } \mathrm{X}_{2} \\
& \text { (harga / price) } \\
\beta_{3}= & \text { koefisien regresi dari variabel } \mathrm{X}_{3} \\
& \text { (promosi / promotion) } \\
\beta_{4}= & \text { koefisien regresi dari variabel } \mathrm{X}_{4} \\
& (\text { lokasi / place) } \\
\mathrm{X}_{1}= & \text { produk (product) } \\
\mathrm{X}_{2}= & \text { harga (price }) \\
\mathrm{X}_{3}= & \text { promosi } \text { (promotion) } \\
\mathrm{X}_{4}= & \text { lokasi } \text { (place }) \\
\mathrm{e}= & \text { variabel penggangu }
\end{aligned}
$$

\subsection{Uji Hipotesis}

Pengujian hipotesis dari penelitian ini menggunakan 2 uji yaitu : uji t untuk mengetahui variabel bauran pemasaran yang berpengaruh secara parsial terhadap keputusan pembelian dan uji $\mathrm{F}$ untuk mengetahui variabel bauran pemasaran yang berpengaruh secara simultan terhadap keputusan pembelian.

\subsubsection{Uji Koefisien Determinasi $\left(R^{2}\right)$}

Koefisien determinasi $\left(R^{2}\right)$ artinya mengukur seberapa jauh kemampuan model dalam menjelaskan variabel bebas terhadap variabel terikat.

\section{HASIL DAN PEMBAHASAN 4.1 Uji Validitas}

Hasil perhitungan uji validitas variabel produk $\left(\mathrm{X}_{1}\right)$, harga $\left(\mathrm{X}_{2}\right)$, promosi $\left(\mathrm{X}_{3}\right)$, lokasi $\left(\mathrm{X}_{4}\right)$ dan keputusan pembelian $(\mathrm{Y})$ berdasarkan 23 item pertanyaan dari 100 respnden. Hasil uji validitas pada seluruh butir pertanyaan menghasilkan keseluruhan data valid dengan nilai $r_{\text {hitung }}>r_{\text {tabel }}(0,1966)$ dengan signifikansi $<\alpha$ sebagaimana disajikan dalam Tabel 3.

Tabel 3. Hasil Uji Validitas Variabel Produk $\left(\mathbf{X}_{1}\right)$, Harga $\left(\mathbf{X}_{2}\right)$, Promosi $\left(\mathbf{X}_{3}\right)$, Lokasi $\left(\mathrm{X}_{4}\right)$ dan Keputusan Pembelian (Y)

\begin{tabular}{|c|c|c|c|c|}
\hline $\begin{array}{c}\text { Buti } \\
\mathbf{r}\end{array}$ & $\mathbf{r}_{\text {hitung }}$ & $\mathbf{r}_{\text {tabel }}$ & Sig. & $\begin{array}{c}\text { Krite } \\
\text { ria }\end{array}$ \\
\hline & $\begin{array}{c}\text { PRODUK } \\
(\mathrm{X} 1)\end{array}$ & & & \\
\hline 1. & 0,608 & 0,1966 & 0,000 & Valid \\
\hline 2. & 0,537 & 0,1966 & 0,000 & Valid \\
\hline 3. & 0,562 & 0,1966 & 0,000 & Valid \\
\hline 4. & 0,719 & 0,1966 & 0,000 & Valid \\
\hline & $\begin{array}{c}\text { HARGA } \\
\left(\mathrm{X}_{2}\right)\end{array}$ & & & \\
\hline 5. & 0,463 & 0,1966 & 0,000 & Valid \\
\hline 6. & 0,593 & 0,1966 & 0,000 & Valid \\
\hline 7. & 0,535 & 0,1966 & 0,000 & Valid \\
\hline 8. & 0,534 & 0,1966 & 0,000 & Valid \\
\hline 9. & 0,660 & 0,1966 & 0,000 & Valid \\
\hline & $\begin{array}{c}\text { PROMOSI } \\
\left(\mathrm{X}_{3}\right)\end{array}$ & & & \\
\hline 10. & 0,404 & 0,1966 & 0,000 & Valid \\
\hline 11. & 0,520 & 0,1966 & 0,000 & Valid \\
\hline 12. & 0,660 & 0,1966 & 0,000 & Valid \\
\hline 13. & 0,663 & 0,1966 & 0,000 & Valid \\
\hline 14. & 0,500 & 0,1966 & 0,000 & Valid \\
\hline 15. & 0,542 & 0,1966 & 0,000 & Valid \\
\hline 16. & 0,624 & 0,1966 & 0,000 & Valid \\
\hline 17. & 0,487 & 0,1966 & 0,000 & Valid \\
\hline 18. & 0,440 & 0,1966 & 0,000 & Valid \\
\hline 19. & 0,615 & 0,1966 & 0,000 & Valid \\
\hline & LOKASI & & & \\
$\left(\mathrm{X}_{4}\right)$ & & & \\
\hline 20. & 0,609 & 0,1966 & 0,000 & Valid \\
\hline 21. & 0,690 & 0,1966 & 0,000 & Valid \\
\hline 22. & 0,669 & 0,1966 & 0,000 & Valid \\
\hline & & & & \\
\hline
\end{tabular}




\begin{tabular}{|c|c|c|c|c|}
\hline $\begin{array}{c}\text { Buti } \\
\mathbf{r}\end{array}$ & $\mathbf{r}_{\text {hitung }}$ & $\mathbf{r}_{\text {tabel }}$ & Sig. & $\begin{array}{c}\text { Krite } \\
\text { ria }\end{array}$ \\
\hline 23. & 0,600 & 0,1966 & 0,000 & Valid \\
\hline
\end{tabular}

\subsection{Uji Reliabilitas}

Kriteria reliabilitas pertanyaan kuesioner menurut Gozali (2005) sebagaimana disajikan dalam Tabel 4.

Tabel 4. Kriteria Reliabilitas

\begin{tabular}{|c|c|}
\hline Cronbach Alpha & Kriteria \\
\hline $0,00-0,20$ & Sangat Tidak Reliabel \\
\hline $0,21-0,4$ & Tidak Reliabel \\
\hline $0,41-0,6$ & Cukup Reliabel \\
\hline $0,61-0,8$ & Reliabel \\
\hline $0,81-1,0$ & Sangat Reliabel \\
\hline
\end{tabular}

Sumber : Imam Ghozali (2005)

Hasil uji reliabilitas pada seluruh variabel dan membandingkan kriteria reliabilitas pada Tabel 4 menunjukkan variabel produk $\left(\mathrm{X}_{1}\right)$, harga $\left(\mathrm{X}_{2}\right)$, lokasi $\left(\mathrm{X}_{4}\right)$ dan keputusan pembelian (Y) merupakan variabel yang cukup reliabel sedangkan promosi $\left(\mathrm{X}_{3}\right)$ merupakan variabel yang reliabel. Perhitungan uji reliabilitas dalam penelitian ini menggunakan bantuan komputer dengan program SPSS sebagaimana disajikan dalam Tabel 5.

Tabel 5. Hasil Uji Reliabilitas

\begin{tabular}{|l|c|c|c|}
\hline Variabel & $\begin{array}{c}\text { Variab } \\
\text { el }\end{array}$ & $\begin{array}{c}\text { Cronbach } \\
\text { Alpha }\end{array}$ & $\begin{array}{c}\text { Interpret } \\
\text { asi }\end{array}$ \\
\hline Produk & $\left(\mathrm{X}_{1}\right)$ & 0,432 & $\begin{array}{c}\text { Cukup } \\
\text { reliabel }\end{array}$ \\
\hline Harga & $\left(\mathrm{X}_{2}\right)$ & 0,445 & $\begin{array}{c}\text { Cukup } \\
\text { reliabel }\end{array}$ \\
\hline Promosi & $\left(\mathrm{X}_{3}\right)$ & 0,736 & Reliabel \\
\hline Lokasi & $\left(\mathrm{X}_{4}\right)$ & 0,523 & $\begin{array}{c}\text { Cukup } \\
\text { reliabel }\end{array}$ \\
\hline $\begin{array}{l}\text { Keputusan } \\
\text { Pembelian }\end{array}$ & $(\mathrm{Y})$ & 0,583 & $\begin{array}{c}\text { Cukup } \\
\text { reliabel }\end{array}$ \\
\hline
\end{tabular}

\subsection{Uji Asumsi Klasik}

\subsubsection{Uji Normalitas}

Berdasarkan hasil uji KolmogrovSmirnov pada Tabel 6 diperoleh nilai
Asymp. Sig. (2-tailed) sebesar $0,175>\alpha$ $(0,1)$. Berdasarkan hasil tersebut dapat dinyatakan data yang digunakan dalam penelitian ini telah berdistribusi normal.

Tabel 6. Hasil Uji Normalitas

Kolmogorov-Smirnov Test

\begin{tabular}{|ll|r|}
\hline & & $\begin{array}{r}\text { Unstandardized } \\
\text { Residual }\end{array}$ \\
\hline $\mathrm{N}$ & Mean & 100 \\
Normal & Std. & $0 \mathrm{E}-7$ \\
Parameters $^{\mathrm{a}, \mathrm{b}}$ & Deviation & 1.01440262 \\
& Absolute & .110 \\
Most Extreme & Positive & .110 \\
Differences & Negative & -.085 \\
& Kolmogorov-Smirnov Z & 1.103 \\
Asymp. Sig. (2-tailed) & .175 \\
\hline
\end{tabular}

\subsubsection{Uji Multikolinieritas}

Tabel 7 menunjukkan bahwa diperoleh nilai VIF $<10$ dan nilai tolerance $>\alpha(0,1)$. Oleh karena itu dapat dijelaskan semua variabel dalam penelitian ini tidak terjadi multikolinearitas.

Tabel 7. Hasil Uji Multikolinearitas

\begin{tabular}{|l|c|c|c|}
\hline \multirow{2}{*}{$\begin{array}{c}\text { Variabe } \\
1\end{array}$} & \multicolumn{2}{|c|}{$\begin{array}{c}\text { Collinearity } \\
\text { Statistics }\end{array}$} & \multirow{2}{*}{ Keterangan } \\
\cline { 2 - 3 } & $\begin{array}{c}\text { Toleranc } \\
\mathrm{e}\end{array}$ & VIF & \\
\hline $\begin{array}{l}\text { Produk } \\
\left(\mathrm{X}_{1}\right)\end{array}$ & 0,921 & 1,086 & $\begin{array}{c}\text { Tidak terjadi } \\
\text { multikolinearit } \\
\text { as }\end{array}$ \\
\hline $\begin{array}{l}\text { Harga } \\
\left(\mathrm{X}_{2}\right)\end{array}$ & 0,799 & 1,251 & $\begin{array}{c}\text { Tidak terjadi } \\
\text { multikolinearit } \\
\text { as }\end{array}$ \\
\hline $\begin{array}{l}\text { Promosi } \\
\left(\mathrm{X}_{3}\right)\end{array}$ & 0,849 & 1,178 & $\begin{array}{c}\text { Tidak terjadi } \\
\text { multikolinearit } \\
\text { as }\end{array}$ \\
\hline $\begin{array}{l}\text { Lokasi } \\
\left(\mathrm{X}_{4}\right)\end{array}$ & 0,844 & 1,185 & $\begin{array}{c}\text { Tidak terjadi } \\
\text { multikolinearit } \\
\text { as }\end{array}$ \\
\hline
\end{tabular}

\subsubsection{Uji Heteroskesdastisitas}

Gambar 3 merupakan scatterplot uji heteroskesdastisitas yang menunjukkan titik-titik tidak menyebar secara acak serta bergerombol di bawah angka 0 pada sumbu 
Y. Dengan demikian dapat disimpulkan bahwa data-data yang digunakan dalam model regresi ini tidak terjadi heteroskedastisitas.

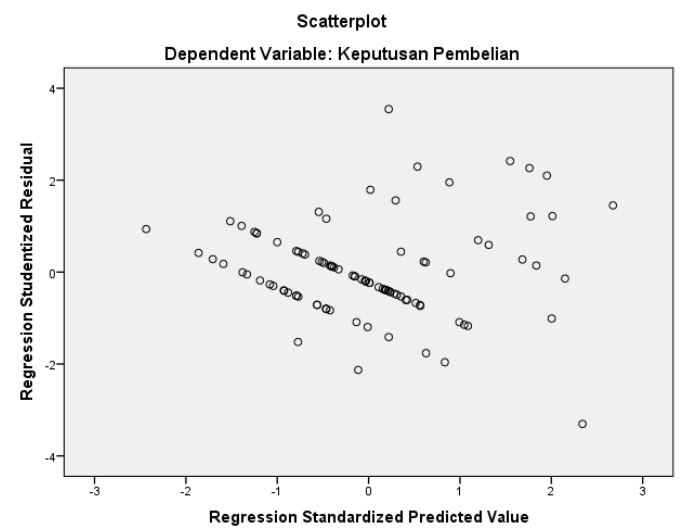

Gambar 3. Scatterplot Hasil Uji

Heteroskesdastisitas

\subsection{Analisis Regresi Berganda}

Analisis regresi berganda bertujuan untuk mengetahui pengaruh antara variabel bebas dan variabel terikat, sekaligus untuk melihat hasil uji hipotesis secara parsial. Untuk mempermudah dalam menganalisis data akan dilakukan dengan menggunakan program SPSS 20. Hasil analisis regresi berganda disajikan pada Tabel 8 .

Tabel 8. Hasil Regresi Berganda dengan Teknik OLS (Ordinary Least Square)

\begin{tabular}{|c|r|r|r|r|r|}
\hline Model & \multicolumn{1}{|c|}{$\begin{array}{r}\text { Unstandardize } \\
\text { d Coefficients }\end{array}$} & $\begin{array}{c}\text { Stan } \\
\text { dardi } \\
\text { zed } \\
\text { Coef } \\
\text { ficie } \\
\text { nts }\end{array}$ & t & Sig. \\
\cline { 2 - 5 } & B & \multicolumn{1}{|c|}{$\begin{array}{c}\text { Std. } \\
\text { Error }\end{array}$} & Beta & & \\
\hline $\begin{array}{c}\text { (Constan } \\
\text { t) }\end{array}$ & 4.176 & 2.301 & & 1.814 & .073 \\
\hline Produk & .221 & .090 & .198 & 2.465 & .015 \\
\hline Harga & .324 & .086 & .326 & 3.772 & .000 \\
\hline Promosi & .019 & .040 & .040 & .480 & .632 \\
\hline Lokasi & .327 & .072 & .383 & 4.551 & .000 \\
\hline
\end{tabular}

Berdasarkan Tabel 8 diperoleh model persamaan regresi sebagai berikut.
$Y=4,176+0,221 X_{1}+0,324 X_{2}+0,019$

$\mathrm{X}_{3}+\mathbf{0 , 3 2 7} \mathrm{X}_{4}$

Interpretasi hasil dari model persamaan regresi di atas yaitu :

1. Konstanta $(\alpha)$ sebesar 4,176, artinya apabila produk, harga, promosi dan lokasi tidak ada atau nilainya adalah 0 , maka keputusan pembelian konsumen (Y) berbelanja di Indogrosir Cibinong akan tetap sebesar 4,176.

2. Koefisien regresi variabel produk $\left(\mathrm{X}_{1}\right)$ sebesar 0,221, artinya setiap peningkatan variabel produk (produk tidak mendekati kadaluarsa, berkualitas baik, tata letak produk rapi dan menarik, kemasan produk tidak berdebu) sebesar 1 satuan maka akan meningkatkan keputusan pembelian (Y) berbelanja di Indogrosir Cibinong sebesar 0,221.

3. Koefisien regresi variabel harga $\left(X_{2}\right)$ sebesar 0,324, artinya apabila variabel harga (harga yang terjangkau, harga yang sesuai kualitas produk, harga yang tertera sesuai dengan harga yang harus di bayar, harga yang kompetitif dan relatif murah, serta harga yang ditawarkan sesuai dengan manfaat produk) ditingkatkan 1 satuan, maka keputusan pembelian konsumen (Y) berbelanja di Indogrosir Cibinong mengalami kenaikan sebesar 0,324 satuan.

4. Koefisien regresi variabel promosi $\left(\mathrm{X}_{3}\right)$ sebesar 0,019, artinya apabila promosi (pamflet, broadcast SMS, potongan harga, hadiah/bonus, member card, promo akhir pekan, katalog promo, website, sponsorship, dan sosial media) ditingkatkan 1 satuan, maka keputusan pembelian konsumen (Y) dalam berbelanja di Indogrosir Cibinong mengalami peningkatan sebesar 0,019 satuan.

5. Koefisien regresi variabel lokasi $\left(\mathrm{X}_{4}\right)$ sebesar 0,327, artinya apabila lokasi 
(lokasi strategis, penataan parkir, area parkir memadai, terjangkau transportasi umum) ditingkatkan 1 satuan, maka keputusan pembelian konsumen (Y) berbelanja di Indogrosir Cibinong mengalami kenaikan sebesar 0,327 satuan.

\subsection{Uji Hipotesis}

\subsubsection{Uji Hipotesis Parsial (Uji t)}

Berdasarkan Tabel 8, menunjukkan nilai $t_{\text {hitung }}$ dan signifikansi masing-masing variabel. Nilai $t_{\text {hitung }}>t_{\text {tabel }}(1,29)$ dan signifikansi $<\alpha(0,1)$ menunjukkan variabel yang berpengaruh secara parsial terhadap keputusan pembelian dan sebaliknya, sebagaimana disajikan dalam Tabel 9.

\section{Tabel 9. Hasil Kriteria Hipotesis Uji t}

\begin{tabular}{|c|c|c|l|l|}
\hline Variabel & T hitung & $\begin{array}{c}\text { Signifi } \\
\text { kansi }\end{array}$ & Hipotesis & Kriteria \\
\hline $\begin{array}{c}\text { Produk } \\
\left(\mathrm{X}_{1}\right)\end{array}$ & 2,465 & 0,015 & $\begin{array}{l}\text { Ha ditolak } \\
\text { dan Ha } \\
\text { diterima }\end{array}$ & $\begin{array}{l}\text { Berpengar } \\
\text { uh }\end{array}$ \\
\hline $\begin{array}{c}\text { Harga } \\
\left(\mathrm{X}_{2}\right)\end{array}$ & 3,772 & 0,000 & $\begin{array}{l}\text { Ha ditolak } \\
\text { dan Ha } \\
\text { diterima }\end{array}$ & $\begin{array}{l}\text { Berpengar } \\
\text { uh }\end{array}$ \\
\hline $\begin{array}{c}\text { Promosi } \\
\left(\mathrm{X}_{3}\right)\end{array}$ & 0,480 & 0,632 & $\begin{array}{l}\text { Ha diterima } \\
\text { dan Ha } \\
\text { ditolak }\end{array}$ & $\begin{array}{l}\text { Tidak } \\
\text { Berpengar } \\
\text { uh }\end{array}$ \\
\hline $\begin{array}{c}\text { Lokasi } \\
\left(\mathrm{X}_{4}\right)\end{array}$ & 4,551 & 0,000 & $\begin{array}{l}\text { Ha ditolak } \\
\text { dan Ha } \\
\text { diterima }\end{array}$ & $\begin{array}{l}\text { Berpengar } \\
\text { uh }\end{array}$ \\
\hline
\end{tabular}

Tabel 9 menunjukkan variabel-variabel yang berpengaruh terhadap keputusan pembelian (Y) adalah produk, harga dan lokasi. Variabel yang tidak berpengaruh terhadap keputusan pembelian (Y) adalah promosi. Variabel promosi tidak berpengaruh terhadap keputusan pembelian karena konsumen yang menjadi responden memang sudah sering berbelanja ke Indogrosir Cibinong. Para konsumen ini biasanya memutuskan membeli karena memang berbelanja sesuai dengan kebutuhan. Para konsumen menyampaikan memutuskan berbelanja karena lokasi dekat dengan rumah mereka, mudah diakses karena di tepi jalan, produknya cukup lengkap sesuai kebutuhan sehingga tidak perlu mencari-cari lagi ke toko lain, dan harga yang ditawarkan juga tidak terlalu mahal. Berdasarkan Tabel 8 dan Tabel 9, dapat ditentukan variabel yang dominan mempengaruhi keputusan pembelian yaitu variabel lokasi. Variabel lokasi, pada Tabel 8 menunjukkan koefisien regresi sebesar 0,327 dan pada Tabel 9 menunjukkan nilai $t_{\text {hitung }}$ yang lebih tinggi dibandingkan variabel lainnya.

\subsubsection{Uji Hipotesis Simultan (Uji F)}

Tabel 10. Hasil Uji Koefisien Regresi Simultan (Uji F)

\begin{tabular}{|c|r|r|r|c|c|}
\hline Model & $\begin{array}{c}\text { Sum of } \\
\text { Squares }\end{array}$ & df & $\begin{array}{c}\text { Mean } \\
\text { Square }\end{array}$ & F & Sig. \\
\hline Regression & 77.838 & 4 & 19.459 & 18.147 & $.000^{\mathrm{b}}$ \\
\hline Residual & 101.872 & 95 & 1.072 & & \\
\hline Total & 179.710 & 99 & & & \\
\hline
\end{tabular}

Tabel 10 diperoleh nilai $F_{\text {hitung }}$ sebesar 18,147 dengan nilai Sig sebesar 0,000 . Hal ini menunjukkan bahwa nilai $F_{\text {hitung sebesar } 18,147>F_{\text {tabel }}(2,01) \text { dan }}$ nilai Sig sebesar $0,000<\alpha(0,10)$. Dengan demikian $\mathrm{H}_{0}$ ditolak dan $\mathrm{H}_{\mathrm{a}}$ diterima, artinya bauran pemasaran yang terdiri dari produk, harga, promosi, dan lokasi secara simultan mempunyai pengaruh yang signifikan terhadap keputusan pembelian di Indogrosir Cibinong. Hipotesis hasil uji $\mathrm{F}_{\text {hitung }}$ disajikan dalam 10.

\subsubsection{Uji Koefisien Determinasi $\left(R^{2}\right)$}

Tabel 11. Hasil Uji Determinasi $\left(\mathbf{R}^{\mathbf{2}}\right)$

\begin{tabular}{|c|c|c|}
\hline $\begin{array}{c}\mathrm{R} \\
\text { Square }\end{array}$ & $\begin{array}{c}\text { Adjusted } \mathrm{R} \\
\text { Square }\end{array}$ & $\begin{array}{c}\text { Std. Error of the } \\
\text { Estimate }\end{array}$ \\
\hline .433 & .409 & 1.03554 \\
\hline
\end{tabular}

Berdasarkan Tabel 11 diperoleh nilai $\mathrm{R}^{2}$ (Adjusted R Square) sebesar 0,409 atau $40,9 \%$. Hal ini menunjukkan bahwa variabel pengaruh bauran pemasaran yang terdiri dari produk $\left(\mathrm{X}_{1}\right)$, harga $\left(\mathrm{X}_{2}\right)$, promosi $\left(\mathrm{X}_{3}\right)$, dan lokasi $\left(\mathrm{X}_{4}\right)$ dapat 
menjelaskan variabel keputusan pembelian (Y) di Indogrosir Cibinong sebesar 40,9\%, sedangkan sisanya yaitu sebesar $59,1 \%$ dijelaskan oleh faktor-faktor lain yang tidak diteliti dalam penelitian ini. Nilai-nilai koefisien determinasi disajikan pada Tabel 11.

\section{KESIMPULAN DAN SARAN}

\subsection{Kesimpulan}

Kesimpulan yang dihasilkan dari penelitian ini yaitu :

1. Variabel yang berpengaruh terhadap keputusan pembelian (Y) adalah produk, harga dan lokasi sedangkan variabel yang tidak berpengaruh terhadap keputusan pembelian (Y) adalah promosi. Variabel promosi tidak berpengaruh terhadap keputusan pembelian karena konsumen sudah sering berbelanja ke Indogrosir Cibinong yang berbelanja sesuai dengan kebutuhan. Para konsumen Omenyampaikan memutuskan berbelanja karena lokasi dekat dengan rumah mereka, mudah diakses karena di tepi jalan, produknya cukup lengkap sesuai kebutuhan sehingga tidak perlu mencari-cari lagi ke toko lain, dan harga yang ditawarkan juga tidak terlalu mahal.

2. Variabel produk, harga, promosi dan lokasi secara simultan berpengaruh terhadap keputusan pembelian konsumen di Indogrosir Cibinong.

3. Variabel dominan yang mempengaruhi keputusan pembelian yaitu variabel lokasi. Variabel lokasi menjadi variabel yang paling berpengaruh karena Indogrosir dekat dengan rumah dan akses lokasi yang mudah.

4. Variabel pengaruh bauran pemasaran yang terdiri dari produk, harga, promosi dan lokasi dapat menjelaskan variabel keputusan pembelian di Indogrosir Cibinong sebesar 40,9\%, sedangkan sisanya yaitu sebesar $59,1 \%$ dijelaskan oleh faktor-faktor lain yang tidak diteliti dalam penelitian ini.

\subsection{Saran}

Saran yang dihasilkan dari penelitian ini yaitu :

1. Indogrosir Cibinong memperhatikan produk dengan cara memperhatikan produk tidak mendekati tanggal kadaluarsa, produk berkualitas baik, kemasan produk yang menarik, dan tidak berdebu serta rapi sehingga konsumen Indogrosir Cibinong merasa sangat puas dengan pelayanan yang diberikan.

2. Indogrosir Cibinong memperhatikan harga dengan cara memberikan harga yang ditawarkan terjangkau, harga yang ditawarkan sesuai dengan kualitas produk, harga yang tertera di rak kasir sesuai dengan harga yang harus di bayar ke kasir, harga yang ditawarkan kompetitif dan relatif murah, serta harga yang sesuai dengan manfaat produk sehingga biaya yang dikeluarkan konsumen untuk memperoleh suatu produk sesuai dengan proporsi nilai produk.

3. Indogrosir Cibinong memperhatikan lokasi dengan cara penataan parkir sehingga memudahkan konsumen ketika keluar dan masuk area Indogrosir, area parkir kendaraan roda dua atau empat cukup memadai yang disediakan untuk konsumen. Indogrosir juga mempertahankan lokasi Indogrosir yang mudah dijangkau oleh transportasi umum dan penempatan lokasi Indogrosir yang strategis sehingga memudahkan konsumen untuk berbelanja di Indogrosir karena lokasinya yang strategis dan mudah dijangkau oleh transportasi umum. 
6. DAFTAR PUSTAKA

Imam Ghozali. (2011). Aplikasi Analisis Multivariate Dengan Program IBM SPSS 19. Semarang: Universitas Diponegoro.

Philip Kotler. (2008). Prinsip-prinsip Pemasaran. Jilid 1. Jakarta: Erlangga.

Kotler, Philip dan Amstrong, Gary. 2012. Marketing Management Edisi 14. Global Edition Pearson Prentice Hall.

Schiffman, Leon G. dan Lesli Laizer Kanuk. 2008. Perilaku Konsumen. Alih Bahasa: Zoelkifli Kasip. Jakarta. PT Indeks.

Suherman, Erman dkk. 2003. Strategi Pembelaran Matematika Kontemporer. Bandung: PT Remaja Rosdakarya.

Rambat Lupiyoadi. (2013). Manajemen Pemasaran Jasa. Jakarta: Salemba Empat.

Schiffman \& Kanuk. (2008). Perilaku Konsumen (edisi 7). Jakarta: Prentice Hall.

Suryadi, Didih. 2011. Promosi Efektif Menggugah Minat dan Loyalitas Pelanggan. Jakarta: PT Suka Buku.

Shinta, Agustina. 2011. Manajemen Pemasaran. Malang: UB Press.

Sugiyono. 2015. Metode Penelitian Pendidikan (Pendekatan Kuantitatif, Kualitatif dan R\&D). Penerbit CV. Alfabeta: Bandung

Sweeney, J. C. 2008. Cognitive Dissonance After Purchase: A Multidimensional Scale. Journal of Psychology \& Marketing.

Utami, Christina Widia. 2010. Manajemen Ritel. Edisi Kedua. Jakarta: Salemba Empat. 